\title{
AL-QURAN EDUCATION PARK TEACHER LEARNING MODEL IN SUPPORTING STUDENT ACHIEVEMENT
}

\section{Muhammad Teguh Saputra}

State University of Jakarta

Email: muhammadteguhsaputra_1404619041@mhs.unj.ac.id

\begin{tabular}{|c|c|}
\hline $\begin{array}{l}\text { Keywords } \\
\text { Learning model, } \\
\text { Adaptation, } \\
\text { Student } \\
\text { achievement } \\
\text { Article Info } \\
\text { Accepted: } \\
\text { June, } \mathbf{2 5}^{\text {th }} \mathbf{2 0 2 1} \\
\text { Revised: } \\
\text { July, } \mathbf{1}^{\text {st }} \mathbf{2 0 2 1} \\
\text { Approved: } \\
\text { July, } \mathbf{9}^{\text {th }} \mathbf{2 0 2 1}\end{array}$ & $\begin{array}{l}\text { Abstrect This study aims to find out what kind of learning } \\
\text { model is used by the teachers of Taman Pendidikan Al-Quran } \\
\text { Musholla Darussalam from time to time, which is explained by } \\
\text { analyzing: (1) what learning paradigm is used, (2) what learning } \\
\text { theory and methods are applied, ( } 3 \text { ) and what activities are } \\
\text { carried out. This research is important to describe because it } \\
\text { raises the learning strategies carried out in research from time } \\
\text { to time, so that they are relevant to the problems of the times } \\
\text { that require teachers to quickly adapt to the dynamic } \\
\text { development of science and technology. The method used in } \\
\text { this research is qualitative in the form of field research. The } \\
\text { results used are: (1) the paradigm used shifts from teacher- } \\
\text { centered to student-centered (2) the theory used consistently } \\
\text { uses behavioristic theory and the dominant method used is the } \\
\text { demo method (3) the activities carried out include; (a) reading } \\
\text { iqra and quran books; (b) summarize books on Islamic creed } \\
\text { and the history of Islamic culture; (c) memorizing the quran and } \\
\text { hadith, and so on. }\end{array}$ \\
\hline
\end{tabular}

\section{Introduction}

Education in this 4.0 era demands the adaptability of teachers (Supandi, Sahrazad, Wibowo, \& Widiyarto, 2020) in following the development of science and technology, including teachers at the early childhood level (Luluk, 2012). Therefore, research is needed that raises the themes of teacher adaptation so that they become examples for other teachers to practice.

The Qur'an Education Park (TPA) is a basic level Quran-based educational institution for children aged 0-12 years (Nurhadi, 2019). Judging from the definition put forward by Anwar, the Qur'an Education Park Musholla Darussalam (MUSDAR TPA) is included in non-formal educational institutions (Anwar, 2021). 


\section{Muhammad Teguh Saputra}

Syaiful Sagala in his research (Tibahary \& Muliana, 2018) on various innovative learning models provides a definition of learning models. According to him, the learning model is a conceptual framework that describes a systematic procedure for teachers in achieving learning objectives. Therefore, regarding strategies, methods, and approaches in learning, it can be said that they are part of the learning model.

In the learning model, there are several learning theories and approaches used by teachers to maximize students' potential in participating in learning (Nurdyansyah \& Fahyuni, 2016). Commonly used learning theories include constructivist, behavioristic, humanistic, and cognitive theories (Husamah, Pantiwati, Restian, \& Sumarsono, 2016). And the two approaches that are commonly used are the teacher-centred and student-centered approaches (Santyasa, 2018).

According to constructivist learning theory, knowledge in humans is built continuously (Saputro \& Pakpahan, 2021). According to the behavioristic learning theory, the learning process can be said to be successful if there is a change in student behavior through habits made during learning (Pratama, 2019). According to constructivist learning theory, learning is a process of forming knowledge by a learner, so that knowledge cannot simply be transferred from teacher to student (Masgumelar \& Mustafa, 2021). According to humanistic learning theory, the learning process must originate in humans, meaning that any theory can be utilized as long as it is intended to humanize humans (Siregar \& Nara, 2010).

The student-centered paradigm is a student-oriented learning paradigm (Wijayanti, 2011). It is the students who are actively learning and the teacher becomes the facilitator so that the students who learn can maximize their potential. While the teacher-centered paradigm is a teacher-oriented teaching paradigm. It is said that teaching is not learning because it is the teacher who actively plays a role in the formation of student knowledge, not the students themselves.

Researchers made the TPA MUSDAR learning model a topic to be researched with the consideration that there were still few who adopted a comprehensive TPA learning model (concerning planning, execution, and evaluation of learning), especially learning models from time to time. Most studies focus on one part of the learning model (only using learning methods or strategies) and one time, as in the research conducted (Partono, Hamengkubuwono, \& Fransiska, 2020) on the example non-example model in demonstration tajwid learning in education subjects. Islam. For this reason, this research is quite important to be appointed. 
Researchers limit the problem to the learning model within the scope of the approaches, methods, and strategies used. Observations were made by using interviews and direct observation of activities, then analyzed based on what the researchers observed. Mr. S the researcher chose as the interview subject because he was the one who taught and headed the TPA Musdar for about 28 years, since the TPA Musdar was founded. He also explained that he was certified as a TPA teacher. For this reason, the data collected in this study can be accounted for.

\section{Method Research}

The type of research adopted is qualitative research, with field research and interviews as methods of data collection. Then, the results of interviews and field observations were analyzed through a literature study. The researcher limits the research subject to Mr. S as a teacher, and Musdar TPA students. The researcher also limits the problem to the learning model within the scope of the approaches, methods, and strategies used by Mr. S as the Musdar TPA teacher.

\section{Result and Discussion}

TPA Musdar is a non-formal school based on Islamic religious knowledge whose students are children aged 3-12 years, so the learning model used can be said to be a fun model and can make students actively move. This TPA was founded in 1993 with the primary goal of reading and writing the Koran. Although in its implementation, the researchers observed that there were activities outside the primary goal, such as learning to draw and eating together.

TPA Musdar in carrying out its learning is divided into two classes based on the learning time, namely morning class and afternoon class. This is done so that students who have entered elementary school (SD) or formal school (aged 7-12 years), can still attend TPA Musdar while not being disturbed by their formal schooling.

TPA Musdar is not constrained by a strict syllabus from the government even though it is officially registered with the nearest government agency. So that in its development, although the learning model at the TPA refers to the TPA syllabus from the Ministry of Religion of the Republic of Indonesia (KEMENAG $\mathrm{RI}$ ), in practice it is widely open to continue to be innovated independently.

In its history from time to time, there have been several changes that have occurred in learning activities at TPA Musdar. The changes in these activities, it indicates a change in the learning model in TPA Musdar as well. Some of these changes researchers divide and review in two periods, namely the early period 


\section{Muhammad Teguh Saputra}

of the present period, and the period of covid-19. Learning activities in the two periods include:

\section{A. Early Period (1993-2014)}

\section{Reading IQRO and Quran books}

The Iqro book compiled by Ustadz As'ad Humam is a book that contains methods for learning the letters of the Koran or the hijaiyah letters in units or in successive ones that are used at the stage before students read the real Quran. This activity is carried out routinely, the aim is that students get used to reading or reading the Koran, so that in the end they can read the Quran fluently.

\section{Pray Before and After Studying}

Every before and after carrying out various learning activities, the teacher will start a song that also contains instructions for students to sit neatly. With these songs, it is easy for the children to be conditioned by the teacher. Because the children consider the song as a form of joy, so the instructions contained in the song are automatically considered a joy for him as well.

\section{Studying Islamic Cultural History Books and Akhlak Akidah Books}

That is, students are given a book or several books that are summarized, studied, and collected by students to the teacher to assess the summary results. If it has reached one semester, what has been learned from what has been summarized will be useful for doing the test, because when the test is written, the questions come from what has been summarized by the students.

This activity is carried out to increase the knowledge treasury, which can later be used by students as a provision of knowledge to be used in formal schools or as a guide to be used in everyday life. This activity is carried out once a week.

\section{Memorizing Hadith and Daily Prayers}

Students are taught hadith through direct practice guided by the teacher through the demonstration method. That is, with the teacher reading the hadith text gradually, then students imitate what the teacher reads. The teacher will repeat the text many times gradually until it is complete, this is done so that students memorize and can recite the hadith texts fluently. This activity is carried out regularly.

\section{Eat Together}

Students are instructed to bring food independently, which then at the appointed time, the food may be eaten together. This is done to strengthen the 
relationship between students with one another, as well as between teachers and parents. This activity is carried out once a week if it is located at the MUSDAR TPA.

\section{Travel}

Before entering the formal school holiday, parents and teachers coordinate to travel to a place that will be visited during the school holidays. The tour agenda is carried out during school holidays, so that students who are already informal school (already entering the elementary/elementary school level), are not disturbed by their formal schooling with activities carried out by the TPA. Students who take part in this tour are expected to be fresher and more enthusiastic in learning, and gain valuable experiences with their family and friends. This activity is carried out once a year.

\section{Memorizing Short Letters}

The method used is demonstration. Short Letters are usually read together by teachers and students repeatedly. The difference between memorizing hadith and daily prayers, memorizing this surah is demonstrated by the teacher reading the Koran text by verse gradually. Then, students accompany the teacher's reading. The teacher will repeat the text many times perverse until it is complete, this is done so that the letter that is read can be memorized by students. This activity is usually done once a week.

\section{Draw}

Students are given a picture book by the teacher which contains pictures of hijaiyah letters, fruits, and animals. For drawing equipment, students bring it independently. Drawing activities are carried out to foster creativity in students. This activity is carried out once a week.

\section{Read Hijaiyah Letters and memorize Arabic Vocabulary}

This activity is carried out using the demonstration method, where the teacher points to an object, then it is called based on the Arabic language. In addition to pointing directly to objects, this activity is also carried out in other ways, namely pointing to the blackboard containing the writings of hijaiyah letters and animals or plants drawn by the teacher.

From the object designated and called by the teacher, then the students follow it. This is so that students are easy to remember and identify hijaiyah letters or Arabic through what is pointed and seen. These activities are carried out regularly.

\section{Sing}




\section{Muhammad Teguh Saputra}

Every before and after carrying out various learning activities, the teacher will start a song that also contains instructions for students to sit neatly. With these songs, it is easy for the children to be conditioned by the teacher. Because the children consider the song as a form of joy, so the instructions contained in the song are automatically considered a joy for him as well.

This is also done so that students become more sympathetic to what is taught by the teacher. The various songs are: (1) pat a pious child, (2) pat sitting sweetly, and so on. This is done regularly.

\section{Exam}

After one semester, the teacher held an exam. This exam is divided into several types, namely written exams, prayer memorization, Quran memorization deposits, and prayer practices. The written test is where students answer the questions listed on the paper. Memorizing prayers and depositing the memorization of the Quran is done by facing the teacher one by one and then depositing it by speaking.

The practice of prayer is carried out by practicing all the movements and readings of prayers that have been taught by the previous teacher. This practice starts from ablution as a condition of valid prayer until the prayer after prayer. This prayer practice is divided into three positions, namely, some students are appointed as imams, some students are appointed as congregations, and some are appointed as muezzins. This activity is carried out once a year.

\section{Distribution of Reports, Ranking Announcements, and Prize Distribution}

After the written test, worship practices, and so on regarding end-of-semester activities, the teacher gives a report card to the parents. This series of activities also includes ranking announcements and the distribution of prizes for outstanding students. This is done so that parents and students can evaluate and improve student achievement. This activity is carried out once a year.

B. The Present (2014 - 2019)

The activities in the TPA MUSDAR to date are almost the same as the initial period, only a few have changed, this is done so that the TPA MUSDAR remains relevant to the changing times. Among the activities that have changed are:

\section{Abolished Exams and Distribution of Reports}

This is done to distinguish between formal schools and non-formal schools. Judging from the main objective, this makes teachers more focused on maximizing the potential of students in the form of writing, reading, and studying 
Islamic religious knowledge rather than being too entangled in administrative matters.

\section{Abolished Eating Together}

The absence of eating together was due to the busyness of the students because it was considered that there was no time to do so, the meal together was abolished.

\section{Held Healthy Gymnastics}

This is done in line with the student's need for physical health so that there is a balance between physical and spiritual.

\section{Participate in Celebrating Islamic Holidays}

This activity is carried out to foster empathy and sympathy for students for religion and the surrounding community, as well as a form of worship to God directly or through intermediaries in social life.

\section{Covid-19 Period (2020 - 2021)}

Activities at the TPA Musdar during the covid-19 period were limited in activities, especially on things that caused students to gather outside the TPA such as traveling. In addition, for the sake of health and government regulations, learning activities are implemented following health protocols, namely by requiring the use of masks.

\section{Conclusion}

Based on the results of the research and discussion, it can be concluded that identified from his various activities, it appears that Mr. S in his learning approach is transformed, from the teacher-centred paradigm to the student-centered paradigm. This is evident from the provision of prizes in the initial period for students who get ranked one, two, and three to the elimination of report cards, the ranking system, and the awarding of prizes. This means that from the initial orientation in the form of how to get students to get good grades to how students can maximize their potential.

Judging from the learning activities described previously, the learning theory used consistently uses Behavioristic theory. According to this theory, the learning process can be said to be successful if there is a change in student behavior through habits made during learning. This is proven, for example, in the routine activities of praying together and singing with the aim that students get used to sitting regularly. 


\section{Muhammad Teguh Saputra}

\section{References}

Anwar, Rosyida Nurul. (2021). Pendidikan Alquran (TPQ) Sebagai Upaya Membentuk Karakter Pada Anak. Jurnal Pendidikan Dan Konseling (JPDK), 3(1), 44-50.

Husamah, Husamah, Pantiwati, Yuni, Restian, Arina, \& Sumarsono, Puji. (2016). Belajar dan pembelajaran. Research Report.

Luluk, Hadiqotul. (2012). Paradoks dalam Peningkatan Kompetensi Guru Paud. Jurnal IImiah Visi, 7(2), 117-129.

Masgumelar, Ndaru Kukuh, \& Mustafa, Pinton Setya. (2021). Teori Belajar Konstruktivisme dan Implikasinya dalam Pendidikan dan Pembelajaran. GHAITSA: Islamic Education Journal, 2(1), 49-57.

Nurdyansyah, Nurdyansyah, \& Fahyuni, Eni Fariyatul. (2016). Inovasi model pembelajaran sesuai kurikulum 2013. Nizamia Learning Center.

Nurhadi, Nurhadi. (2019). Sekolah Bermain (TPI/TPA/TKA/TPQ) dalam Pendidikan Islam. AS-SABIQUN, 1(1), 80-94.

Partono, Partono, Hamengkubuwono, Hamengkubuwono, \& Fransiska, Jeny. (2020). Model Example Non Example Dalam Pembelajaran Tajwid. Belajea; Jurnal Pendidikan Islam, 5(1), 23-36.

Pratama, Yoga Anjas. (2019). Relevansi teori belajar behaviorisme terhadap pendidikan agama islam. Jurnal Pendidikan Agama Islam Al-Thariqah, 4(1), 3849.

Santyasa, I.Wayan. (2018). Student centered learning: Alternatif pembelajaran inovatif abad 21 untuk menyiapkan guru profesional. Quantum: Seminar Nasional Fisika, Dan Pendidikan Fisika.

Saputro, M.Nugroho Adi, \& Pakpahan, Poetri Leharia. (2021). Mengukur Keefektifan Teori Konstruktivisme dalam Pembelajaran. JOEAI: Journal of Education and Instruction, 4(1), 24-39.

Siregar, Eveline, \& Nara, Hartini. (2010). Teori belajar dan pembelajaran.

Supandi, Agus, Sahrazad, Sara, Wibowo, Arief Nugroho, \& Widiyarto, Sigit. (2020). Analisis kompetensi guru: pembelajaran revolusi industri 4.0. Prosiding Samasta.

Tibahary, Abdul Rahman, \& Muliana, Muliana. (2018). Model-model Pembelajaran Inovatif. Scolae: Journal of Pedagogy, 1(1), 54-64.

Wijayanti, Wiwik. (2011). Student Centered; Paradigma Baru Inovasi Pembelajaran. Majalah Ilmiah Pembelajaran, 7(1).

\section{Copyright holder :}

Muhammad Teguh Saputra (2021)

First publication right :

Devotion - Journal of Community Service

This article is licensed under:

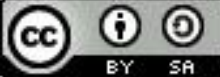

\section{Al-quran education park teacher learning model in supporting student achievement}

